\title{
Contatos: Cruz e Sousa e Berna Reale
}

\author{
Maiara Knihs
}

UFSC

\begin{abstract}
Resumo
Este artigo tem por objetivo colocar em contato dois cenários: a poesia de João Cruz e Sousa (1861-1898) e as performances de Berna Reale (1964-). A breve análise comparativa revela um ponto de ressonância: a violência. No caso do poeta, a questão aparece nas imagens ambivalentes aliadas ao procedimento da sugestão (típico do Simbolismo) e também na musicalidade aliada à precisão formal - sempre colocando em tensão a lei e a transgressão. No caso da artista plástica, as performances analisadas evocam sempre um corpo marcado pela violência: torturado, deteriorado ou preso. De fato, as manifestações artísticas tocam na questão da violência social e humana (inerente à linguagem), mas levantam o problema da violência notadamente mercadológica. A hipótese de leitura que surge, portanto, é a de que a crise que subjaz à arte, nesse caso, relaciona-se à violência do mercado literário/ artístico no Brasil que irrompe no início da República e pervive até a contemporaneidade.
\end{abstract}

Palavras-chave: João da Cruz e Sousa; Berna Reale; Violência; Erotismo.

\begin{abstract}
This article aims to put in contact two scenarios: the poetry of Cruz e Sousa and the performances of Berna Reale. The brief comparative analysis reveals a point of resonance: violence. In the poet's case, the question appears in the ambivalent images combined with the procedure of sugestion (typical of Symbolism) and also in the musicality combined with formal accuracy - always putting in tension law and transgression. In the plastic artist's case, the analyzed performances always evoke a body marked by violence: tortured, defaced or arrested. In fact, both manifestations touch on the issue of social and human violence (inherent in the language), but they raise the problem of violence markedly linked to the rise of modern market economy. The hypothesis of reading that arises, therefore, is that the crisis that underlies the art, in this case, relates to the violence of literary / artistic market in Brazil that bursts at the beginning of the Republic and survives until the present day.
\end{abstract}

Key-words: João da Cruz e Sousa; Berna Reale; Violence; Eroticism. 
1. Nem voz, nem escritura, nem palavra, nem grito, mas rumor transcendental, condição de toda palavra e de todo silêncio, arquia glótica pela qual emito gemidos e prantos, agonia e nascimento, cantarolo e grunho, canção, gozo e sofrimento, palavra imóvel, palavra mumificada, monotonia em que se resolve e se amplifica a polifonia que sobe do fundo do ventre, um mistério de emoção, a união substancial da alma e do corpo, do corpo e da almmmmmma. (Tradução minha)
[...] Ni voix, ni écriture, ni mot, ni cri, mais bruissement transcendantal, condition de tout mot et de tout silence, archie glottique dans laquelle je râle et je vagis, agonie et naissance, je fredonne et je gronde, chanson, jouissance et souffrance, mot immobile, mot momifié, monotonie où se résout et s'amplifie la polyphonie qui monte $d u$ fond $d u$ ventre, un mystère d'émotion, l'union substantielle de l'âme et $d u$ corps, du corps et de l'âmmmmm Jean-Luc Nancy no prefácio de $\mathrm{Mmmmm}^{1}$

O grito que esse texto se põe a escutar é, sobretudo, efeito de uma tensão. A disputa de forças aí, entre tudo aquilo que impele o silenciar - enquanto sorte de ditadura do sentido - e aquilo que rebenta essa univocidade, motor da vida e também da arte, será evidenciado de maneira particular no contraste entre os artistas Cruz e Sousa e Berna Reale. De um lado, o negro filho de escravos que viveu em fins do século XIX, período que ficou marcado pela decadência - extremamente tardia - do sistema escravista e pela grande expectativa encerrada no progresso - que viria com o sistema representativo republicano atrelado à expansão da modernização do país e consequente consolidação do capitalismo. De outro, a mulher que também sofre "na pele" a violência dos discursos que, ainda, pulverizam o patrimonialismo, os interesses individuais em detrimento do público e as suas consequências: a manutenção das autonomias de classe, de gênero, de raça, de identificações em geral. A consequência imediata disso, por sua vez, pode ser observada, por exemplo, no alto índice de violência urbana que Berna acompanha diariamente na sua profissão de perita criminal. Vivendo no século XXI, período já marcado pela contínua constatação de que nem um sistema representativo, nem o capitalismo podem em si significar algum progresso, Berna Reale, assim como Cruz e Sousa, marca no corpo a violência da sociedade e da vida humana. 


\section{Encruzilhada: entre o centro e o excêntrico}

João da Cruz e Sousa, diante da sua condição de negro na provinciana Desterro, escolheu, assim como ressaltou o antropólogo Roger Bastide ${ }^{2}$, a literatura enquanto forma de sublimação do seu desejo. O desejo de escrever, no poeta, sempre esteve aliado ao desejo de ser reconhecido enquanto homem livre e pensante pela classe aristocrática branca. No entanto, o reconhecimento esperado nunca veio, o que o levou a constantes crises financeiras que, por sua vez, o levaram a largar a "ilha" de Santa Catarina e a mudar-se para o Rio de Janeiro. Assim como Andrade Muricy menciona na biografia do poeta ${ }^{3}$, em 1893 foi nomeado praticante de arquivista da Estrada de Ferro Central do Brasil. No ano seguinte, o poeta foi promovido à arquivista, cargo que ocupou até a chegada da tuberculose que o mataria. Nessa função, segundo depoimento dos amigos, numa sorte de repetição do que já havia vivido outrora e diferentemente da sua expectativa inicial, Cruz continuava a sofrer perseguições de toda sorte. Em 1960, a Revista Careta publica um escrito de Gonzaga Duque que ilustra pertinentemente a questão. Diz Gonzaga Duque, referindo-se a Cruz:

Muitas, inúmeras vezes lhe ouvi referências ao fato de ter nascido negro, que ele qualificava de acidental, raramente as fazia com humor, como soem fazer alguns homens intelectuais de sua raça. Era com amargor e acabrunhamento que a isso se referia, e que quando se percebia, ou se supunha motejado por alguém, oriundo da mesma raça, a ofensa revolvia-o profundamente, convulcionava-o, sacudia-o num frenesi desarticulante de mal de São Vito, e arrancava-lhe sarcasmos de represália que pareciam bolas de lama dum estrondo arrasador e estupendos períodos debochativos dum vivo escarninho em que lanhos incisivos da vingança. Assim, de quando em quando, ele me aparecia nervoso, todo trejeitos na figurinha franzina; o duro queixo rapado em arremesso carniceiro de destruir; largas narinas palpitantes no afiliado mestiço do nariz; os olhinhos fulgurantes, a queixar-se que fugira da Repartição porque o chefe, que era mulato, o perseguia e hostilizava.

"É que eu the recordo a origem" - dizia-me -, "tenho talvez a mesma cor da mãe... e ele, que quer ser moreno à força, esbarra-se comigo, vê-me como afirmação tremenda do seu passado, sou o espectro recordativo da mucama que o despejou no mundo!” [.... $]^{4}$

Assim seguia Cruz, ainda segundo o amigo, despejando uma sequência de adjetivos ácidos que muitas vezes eram metamorfoseados em versos. ${ }^{5}$ Em janeiro de 1897, portanto, um
2. Conferir o ensaio "Nostalgia do Branco" em que Bastide, assim como a grande maioria dos críticos da poesia sousiana, atrela a obsessão pelo branco em Cruz e Sousa ao desejo de ascensão social. BASTIDE, Roger. Quatro Estudos sobre Cruz e Sousa. COUTINHO, Afrânio. Cruz e Sousa, 1979 (Col. Fortuna Crítica, v. 4), p.157-189. Originalmente publicado em A Poesia AfroBrasileira, em 1943.

3. MURICY, Andrade. "O cisne Negro: Cruz e Sousa”. In: Revista Interamericana de Bibliografia, 1962.

4. DUQUE, Gonzaga. O poeta negro, 1979, p.98. Originalmente publicado em Careta, Rio de Janeiro, 30 jan., 1960.

5. É importante lembrar que o mote do livro que Paulo Leminski escreve sobre Cruz e Sousa é uma citação que remonta a perseguição mencionada por Gonzaga Duque: "O Setor Pessoal da Estrada de Ferro Central do Brasil vem, por meio desta, denunciar à Diretoria desta Empresa, que foi encontrado em poder de João da Cruz e Sousa, negro, natural de Sta. Catarina, funcionário desta Empresa, na função de arquivista, um poema de sua lavra, como seguinte teor: 'Tu és o louco da imortal loucura,/O louco da loucura mais suprema./A Terra é sempre a tua negra algema,/Prende-te nela a extrema Desventura./Mas essa mesma algema de amargura, /Mas essa mesma Desventura extrema/Faz que tu'alma suplicando gema /E rebente em estrelas de ternura./Tu és o Poeta, o grande Assinalado / Que povoas o mundo despovoado, De belezas eternas, pouco a pouco.../Na Natureza prodigiosa e rica/Toda a audácia dos nervos justifica/Os teus espasmos imortais de louco!' Pede-se providências". Leminski, então, escreve referindose a sua biografia: "Este livro é uma providência" (LEMINSKI, Paulo. Cruz e Sousa, 2003, p.8). Na esteira do poeta paranaense, este artigo continua a responder ao apelo daquela denúncia. 
6. SOUSA, João da Cruz e. Poesia Completa, 1995, p.156158.

7. No poema "Cristo de bronze”, por exemplo. ano antes de morrer, escreve o poema "Canção negra", dedicando-o ao amigo Nestor Vitor que, naquele período, escrevia uma monografia sobre a poesia do poeta, afetado que estava pelo livro Evocações, na ocasião, ainda no prelo. No poema que seria reunido no volume denominado Faróis, organizado postumamente por Nestor Vitor, a boca ganha destaque nas quinze quadras numa sorte de ambiguidade da qual emergem o conhecido e o desconhecido, o sofrimento e o prazer, a impossibilidade de ter e a sublimação. Essa boca, aberta e pútrida ferida, ri, assim como a do arlequim ou a do "acrobata da dor" - como prefere chamá-lo Cruz -, mas também cospe, clama, ruge, uiva, corta como a um golpe, canta rudes trovas, vomita todo o fel. A boca torna-se ambivalente: não canta só o louvor aos deuses e heróis - cria mitos -, mas usa o hino para subverter, assim como fez Baudelaire, as leis do gênero, em última instância, os valores morais:

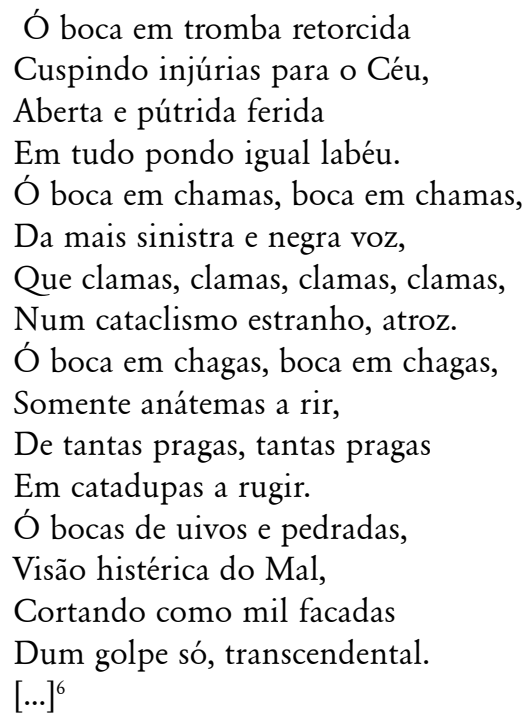

Usar a boca para fins baixos, assim como o corpo rijo de Cristo $^{7}$, é rebaixá-la à sua condição animalesca, violenta, excessiva, maldita: "Bendita seja a negra boca/ Que maldita coisas diz!”, encerra o poema. A boca ressaltada na contradição entre o civilizatório e o selvagem, canal que possibilita a construção identitária e, ao mesmo tempo, que evacua o sofrimento, a dor, a tristeza, coincide com a boca que Georges Bataille definiu em seu verbete:

Nos homens civilizados, a boca até mesmo perdeu a característica relativamente proeminente que ainda se mantém nos homens selvagens. Todavia, o violento significado da boca é preservado em estado latente: de repente, ele vem à tona com uma expressão literalmente canibal como boca de fogo, aplicada aos canhões com os quais os homens se matam. E, nas grandes ocasiões, a vida humana ainda se 
concentra de forma bestial na boca, a cólera faz ranger os dentes, o terror e o sofrimento atroz fazem da boca o órgão dos gritos dilacerantes.

Sobre este assunto, é fácil observar que o indivíduo perturbado levanta a cabeça, tencionando freneticamente o pescoço, de modo que sua boca tenta, ao máximo, ocupar o prolongamento da coluna vertebral, ou seja, a posição que ela normalmente ocupa na constituição animal- como se impulsões explosivas jorrassem diretamente do corpo pela boca, sob forma de vociferações. $[. . .]^{8}$

Anacronicamente, Bataille parece descrever os semblantes que aparecem na poesia de Cruz e Sousa. ${ }^{9}$ As femmes fatales que ali aparecem sempre vinculadas ao erotismo e à morte mostram a sua face como em Lésbia: "Nesse lábio mordente e convulsivo,/ Ri, ri risadas de expressão violenta", ${ }^{10}$ mas não só aí, como em todas as máscaras utilizadas pelo poeta, a ambiguidade da boca é contemplada: a boca que canta é também a que berra.

Essa ambivalência que a boca encena poderia ser colocada em outros termos, por exemplo, a indeterminação entre o domínio da cultura e o domínio do sensível, ou, assim como prefere Jean-Luc Nancy no livro $A$ l'écoute, em termos do regime da visão (representável) e do som (irrepresentável). Aliás, o filósofo, seguindo a linhagem francesa do pós-estruturalismo, ao questionar-se sobre os sentidos sensatos e os sentidos sensíveis, trata de driblar essa dicotomia e inserir um terceiro elemento no cálculo: o espaço comum entre o sentido e o som. Esse lugar intersticial, por excelência, é o espaço em que ambos os elementos participam. Na defesa de Nancy, esse é o lugar próprio da remissão. Assim, o sentido seria a remissão de um signo à alguma coisa. $\mathrm{O}$ som, ainda seguindo o pensamento do pensador francês, seria a remissão de ondas no espaço em que ressoa. Por esse motivo, não se pode perder a dimensão do som enquanto ressoar-se em si, justamente aí o som liga-se à sensação da vibração, logo, à ressonância no corpo. ${ }^{11}$ Daí que o sonoro possa ser pensado muito mais com a tendência do contato, da participação, da repartição do que o visível (o olhar) que tende sempre, ao menos historicamente, para a representação e para a mimese.

Esse contato que nos interessa, prefigurado na subversão conteudística do hino, faz sentir-se, sobretudo, no ritmo, isto é, no tempo que se faz espaço na poesia sousiana. Falar de som, de espaço e tempo ou de tempo que se faz espaço, implica falar de ritmo. O tempo do tempo é um estremecimento do próprio tempo, aquilo que atravanca a sucessão linear da sequência ou duração. Os versos octassílabos do poema "Canção negra”, esse hino negativo, ressoam com acento aristocrático e clássico do verso preferido de Villon. Simultaneamente servem

\section{Documents, 5, ano II, 1930.}

9. No poema "Múmia", um semblante construído para a morte, observa-se na segunda estrofe do soneto:"Tua boca voraz se farta e ceva/Na carne e espalhas o terror maldito,/O grito humano, o doloroso grito/Que um vento estranho para és limbos leva."(SOUSA, João da Cruz e. Poesia

Completa, 1995. p.65) A boca em Cruz é sempre trabalhada ambivalentemente, no poema “Tulipa Real, por exemplo, "Há músicas, há cânticos, há vinhos/ $\mathrm{Na}$ tua estranha boca sulferina." Ibidem, p. 79-80.

10. Ibidem, p. 65.

11. Cabe lembrar, assim como o fez Nancy, que o próprio sentir aristotélico (aesthesis) carrega essa dimensão reflexiva do "sentir-se". 
12. FONSECA, Jair Tadeu. Cruz e Sousa: as expansibilidades do emparedado, 2003.

13. Ibidem, p.63. para dar voz à boca emudecida do negro em fins do século XIX no Brasil. Cruz, entusiasta das formas fixas, perfeccionista nos ritmos, priorizou a música nas suas formas e escolha vocabular, modo de vibrar no corpo o sentido, numa sorte sempre de perversão própria do filósofo, do crítico, do artista. O que poderia ser pensado como um colocar-se em tensão consigo mesmo, que não é outra coisa que se colocar em relação.

Essa operação relacional implica a queda de toda e qualquer autonomia, a dos gêneros líricos, mas também a do sujeito, a do objeto, a da raça, a da classe etc. Dito de outro modo, o procedimento e acento sonoro na poesia sousiana torna indissociável o "eu" e o "outro", o "singular" e o "plural", o "significante" e o "insignificante". Não podemos esquecer de acrescentar nesse rol, no entanto, que também fica entrecruzado nesse fazer poético, o desejo de centro e a excentricidade. Se, assim como assinalou Jair Tadeu Fonseca na sua leitura de o "Emparedado"12, não se pode ler a literatura de Cruz pelo viés da fatalidade da raça, muito menos forjar uma leitura que o enquadre na "literatura negra", também não se pode ignorar as relações de poder que estavam imbricadas na apropriação daquela modalidade poética -no caso, o simbolismo europeu. Ora, o que irrompe na poesia de Cruz, seja pelas imagens (boca), seja pela musicalidade atrelada ao máximo formalismo, seja pelo pungente procedimento da sugestão base dessa poética, é um campo de batalha. Atento a esse aspecto e à recorrência da crítica numa leitura "racial” da poesia, escreveu Fonseca:

Nesse dilaceramento nos vemos, quando tratamos desse tema e vivemos os problemas "raciais". Nesse dilaceramento encontramos Cruz e Sousa. Na encruzilhada das culturas, onde elas se confrontam e, de modo conflituoso, se mesclam. É que a "mestiçagem" cultural não se dá sem problemas, por motivos óbvios: há sempre um pólo dominante nesses encontros de culturas. E não há dúvida de que num caso como o de Cruz e Sousa, um poeta, o pólo que domina é o da cultura branca, de origem européia, aclimatada no Brasil. No campo da literatura, como em outras áreas, não há como escapar disso completamente, porque a poesia, como a entendemos, é uma modalidade artística e uma prática cultural marcadas pelos parâmetros das civilizações européias - justamente as que dominaram política e economicamente o mundo nos últimos séculos. ${ }^{13}$

De maneira refinadamente subversiva, a análise que traz Fonseca, em afinidade com a proposta de Nancy, é uma sorte de reivindicação para um lugar de pensamento e, por extensão, da própria poesia. Escapando da perigosa inversão da leitura da poesia pelo viés da margem, isto é, não em função de uma identidade com a Europa (centro), nem meramente em função de uma identidade com o negro (colonizado), esses autores 
nos permitem pensar que a força colonizadora com a qual havemos de nos dar, na arte ou na vida, deve politicamente ser pensada pelo viés da antropofagia, sem cairmos na inocência ou no esquecimento de que fomos/somos, lembra Fonseca, catequizados. A poesia de Cruz, dessa maneira entendida, é um vestígio da violência (colonizadora).

\section{Corpo de delito}

Até agora, pensou-se como mecanismos da poesia que aparecem na poética sousiana, a subversão do gênero, o ritmo, a própria sugestão característica do simbolismo, funcionam como um apelo ao leitor que não só olha, mas também é atravessado pelas imagens que o veem, como diria Didi-Huberman desdobrando o pensamento benjaminiano sobre o cinema. Ora, a implicação do sujeito nesse sentido teria, ao menos, duas consequências: há um desfoque da relação ingênua entre o som/imagem e o sentido, em última instância, que leva à queda da representação; e, como decorrência da primeira, o sujeito implicado na cena interpretativa abandona o papel de passividade e univocidade diante do objeto e assume um papel de investigador ativo, ou seja, assume a sua responsabilidade política na ação. Assim como o arquivista que arma séries constituindo sentidos, a perita criminal, Berna Reale, apresenta em 2012, uma performance intitulada "Sem título" que incorpora essa questão a partir da ideia da violência (de Estado ?):

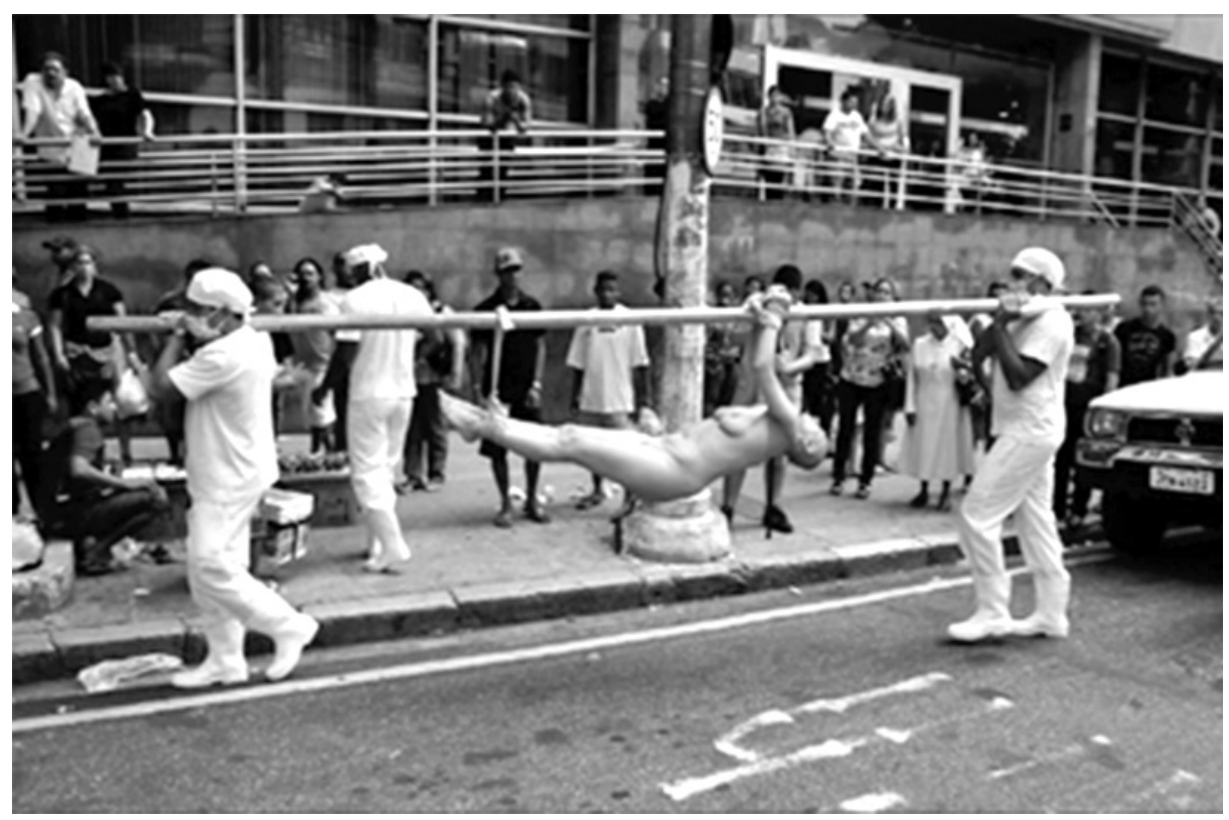

Fig. 01 - Fotografia da performance realizada em 2012 pelas ruas da cidade de Belém. ${ }^{14}$
14. A fotografia da artista que, consultada, cedeu gentilmente o uso da sua imagem para este artigo foi retirada do site do PIPA (Prêmio Investidor Profissional de Arte): http:// www.pipa.org.br/pag/bernareale/ acessado em 20 de julho de 2013. 
15. É possível visualizar na rede parte da performance. $\mathrm{Na}$ reportagem que a revista Bravo! fez sobre a artista, há um vídeo da performance que aqui cito: http://bravonline. abril.com.br/materia/artistavisceral\#image $=$ extra-ernani- 1

16. Inicialmente a performance tinha sido intitulada "Limite Zero".

17. Muitas sobreviventes do regime militar narram que ao pedirem para que o torturador lhes tirasse a vida, a resposta era invariável: não me interessa te matar. Rosalinda Santa Cruz no documentário Quem bom te ver viva, afirma que foi com um riso no rosto que o seu torturador respondeu ao seu apelo de morte. Segundo ela, em seguida ele falou: "Eu não te mato, não me interessa te matar. Eu vou te fazer em pedacinhos. Eu vou te torturar o quanto eu quiser. Inclusive, eu the mato, se eu quiser" A impotência da vítima diante do torturador é inversamente proporcional ao poder que o Estado exerce no seu corpo. Muitas das vezes, a tortura não tinha um objetivo de obtenção das informações, elas ocorriam como repressão à rebeldia dos que resistiam à ditadura. Isto é, por crueldade. Exemplos dessas atrocidades são comuns na história. Bataille no estudo da guerra, enquanto dispêndio de energia que será abordado posteriormente nesse texto, toma exemplos de Maurice Dayie:

$\mathrm{Na}$ África torturam e matam freqüentemente os prisioneiros de guerra ou deixam-nos morrer de fome. Entre os povos de língua tchi, os prisioneiros são tratados com uma barbárie chocante. Homens, mulheres e crianças - mães com seus bebês nas costas e outros filhos mal na idade de caminhar - são postos nus e amarrados com
$\mathrm{Na}$ imagem acima, foto da performance mencionada, Berna está sendo carregada em uma rua de um bairro de Belém, amarrada nua em suporte metálico que nos remete imediatamente ao pau-de-arara, por dois homens vestidos de branco com máscaras e botas brancas. Assim como nos informa a artista, em entrevista concedida ao programa "Jô Soares" em 12 do julho de 2012, a performance foi realizada em seis diferentes bairros da cidade de Belém do Pará. Ela era retirada de um caminhão frigorífero e carregada por quatro quarteirões sentindo no próprio corpo a dor da tortura. Ao ser questionada quanto à reação do público, a artista respondeu que assim como em outras performances, sintomaticamente, a polícia interferiu, nesse caso, graças ao pedido da população que acreditava que um cadáver era carregado nu pelas ruas. Outras manifestações por parte do público rondaram em torno de comentários como "coitada”, "cobre ela”, "do que ela morreu?", comentou, também, a artista.

A julgar pelo caminhão frigorífico de onde o "corpo" é retirado ${ }^{15}$, os homens assumem o papel de açougueiros que carregam, portanto, um pedaço de carne. Assim, está posta a alegoria do açougue que não é outra que a do sacrifício esvaziado e "sem limites"16 do consumismo. A minuciosa montagem da performance, que envolveu inclusive um treinamento para suportar as dores que aparecem de maneira pungente e quase que imediatamente na posição do pau-de-arara, traz, portanto, por meio da alegoria mencionada, a imagem violenta da vida cotidiana notadamente capitalista. A violência materializada no modo como é carregada, torna-a um personagem impotente, amarrado e torturado, sorte de violência com requinte de crueldade ao qual somos todos nós submetidos e nos submetemos diariamente nas relações marcadas pela economia. Nesse contexto, é a faceta animalesca do ser humano, chamada "sem limite", que é exposta e que nos remete, ao mesmo tempo, às ditaduras latino-americanas e à sua íntima relação com o imperialismo mercadológico estado-unidense.

O caráter insuportável e repetitivo dessa crueldade - assinalada no corpo dos escravos ou dos presos políticos - também se presentifica na performance de Berna sob forma de angústia nos transeuntes. As pessoas que assistem chamam a polícia, tentam reestabelecer a lei, isto é, impor um limite (impossível) àquela violência que sentem e recordam no efeito de pena, nojo, dó, horror, embaraçamento. Tudo isso é certamente acentuado pela falta de palavras (de fala) na performance. $\mathrm{O}$ silêncio ressoa ainda mais alto o nonsense que subjaz naquela imagem-movimento na rua. Um corpo ressoa um morto. Um corpo amarrado tal qual um animal ressoa um sacrifício.

O legítimo desejo de atribuir um sentido, que irrompe na forma de angústia no espectador, tem de ser pensado para 
além da ditadura de um sentido único. De fato, a imagem nos remete às sessões de choque elétrico, normalmente, com os corpos nus pendurados no pau-de-arara. Logo, lança-nos também à apropriação do corpo pelo Estado, evocando a violência sexual, o uso de jacarés, baratas, entre outros métodos de tortura. Nesse regime, o corpo é sintoma da violência inerente à manutenção da lei. Aliás, o corpo é radicalmente reificado, ao ponto de a vida do sujeito ficar à mercê do grande Pai, do Estado. ${ }^{17}$ Essa coisificação aliada ao nu no corpo feminino, de soslaio, toca também nos discursos machistas da sociedade contemporânea, nos quais facilmente a mulher recai na posição de objeto passível de propriedade masculina, posicionada a priori, portanto, numa escala inferior da hierarquia do poder.

De todo modo, o corpo (tanto o feminino, quanto o masculino) enquanto objeto - de tortura - tanto na alegoria da performance referida, como nos casos de tortura em regimes ditatoriais, põe em evidência um corpo que, não mais idealizado ou autônomo, como o pensava Kant, por exemplo, se mostra em pedaços. Não por acaso, no livro Faróis de Cruz e Sousa, o corpo aparece fragmentado, na sequência de poemas "Cabelos", "Olhos", "Boca”, "Seios”, "Mãos", "Pés” e "Corpo". Mais relevante que esse esquartejamento, no entanto, é a constante alusão do corpo deteriorado ${ }^{18}$.

O corpo morto, matéria do trabalho de Berna e semblante recorrente nos poemas de Cruz, cria o nojo e a atração motivada pelo horror da morte, mas essa manifestação aparece muitas vezes somente no nojo, nas fobias e não diretamente vinculadas ao cadáver ${ }^{19}$. É válido frisar que se há horror com a identificação do cadáver, também há atração, ou por outra via, também existe a vontade de matar, que na evidente queda dos sistemas religiosos, portanto, do desrespeito à lei "não matarás", e com a falta de direcionamento da inerente violência (como na guerra, em festas, em sacrifícios) explode na banalização de assassinatos que, ao menos momentaneamente, dão ao ser humano a sensação de eternidade. Estamos todos à mercê dessa violência na sociedade contemporânea.

Em relação a essa violência e à angústia produzida por ela, a artista, vencedora do prêmio PIPA online $2012^{20}$, fez o trabalho "Entretantos améns". As fotografias resultantes do trabalho são o registro da artista posicionada diante do mar, traduzindo um efeito de infinito ou impotência diante da mansidão marítima, com uma camisa de força vermelha. A evocação da loucura, da perda de controle, diante do caos, dos altos índices de violência que a perita lida diariamente, mas também da lida diária com o preconceito racial da sociedade branca aristocrática com a qual Cruz e Sousa convivia- a relação não é mera coincidência, sabemos do destino do pretos libertos da escravidão e dos índios catequizados pelos jesuítas- é mote de um dos poemas mais pungentes de Cruz, o "Emparedado". cordas em volta do pescoço, em grupos de dez ou quinze; cada prisioneiro, além disso, é preso pelas mãos a um bloco de madeira grosso que deve ser levado na cabeça. Assim castigados, e insuficientemente alimentados, de modo a serem reduzidos à condição de esqueletos, eles vão a reboque, mês após mês, atrás do exército vitorioso; os guardas brutais tratam-nos com uma extrema crueldade; e se os vencedores sofrem um revés, são imediatamente massacrados sem distinção, a fim de não recordarem a liberdade. (BATAILLE, Georges. O erotismo., 1987, p.52.)

18. Há poemas, como é o caso de "A ironia dos vermes" que a deterioração do corpo é a marca inegável do que nos une - indistintamente de classe ou de cor.

19. Maria do Carmo Brito, por exemplo, no depoimento que aparece no documentário Que bom te ver viva, diz que quando estava menstruada no pau-de-arara causava incômodo de modo que os torturadores a vestiam com uma calça suja, certamente, pela angústia causada pelo sangue de menstruação vinculado ao interdito da morte. Assim como a cor de pele lembra ao patrão mulato de Cruz a sua condição, o sangue lembra ao torturador, tal qual um corpo em

decomposição, a condição finita e miserável do ser humano.

20. O prêmio PIPA (Prêmio Investidor Profissional de Arte) é concedido anualmente, por meio de indicação, a artistas que vem se destacando no cenário brasileiro na modalidade de arte visual contemporânea. 
21. Especificamente para Nestor Vítor, o pensamento que aparece no Emparedado é o pivô em torno do qual giram todas as questões em Cruz e Sousa. CF.: FUNDAÇÃO CASA DE RUI BARBOSA. Obra crítica de Nestor Vitor. Volume I., 1969.

22. SOUSA, João da Cruz e. Poesia Completa, 1995, p. 673.

23. A violência em Benjamin é pensada na ambiguidade com o poder, como a palavra "gewalt" sugere.
Tanto Nestor Vítor, amigo de Cruz e crítico de sua obra e, posteriormente, Andrade Muricy - os grandes responsáveis pela reunião e retomada da obra do poeta - concordam que o "Emparedado" é o poema que encerra a concepção mais acabada de literatura para $\mathrm{Cruz}^{21}$. Nesse poema, retomada explícita da soturnidade de Edgar Allan Poe, o poeta do Desterro faz uma intensa reflexão sobre uma civilização engessadora, preconceituosa e que, em última instância, mesmo no momento de ascensão do capitalismo - do "progresso" - em termos de relações humanas, continua operando via discursos opressores que, não raro, culminam nas mais variadas gradações de violência, atrelada às questões de raça, classe ou gênero. Sobre esse irônico e angustioso implícito progresso, Cruz assim encerra o poema em questão:

Se caminhares para a direita baterás e esbarrarás ansioso, aflito, numa parede horrendamente incomensurável de Egoísmos e Preconceitos! Se caminhares para a esquerda, outra parede, de Ciências e Críticas, mais alta do que a primeira, te mergulhará profundamente no espanto! Se caminhares para a frente, ainda nova parede, feita de Despeitos e Impotências, tremenda, de granito, broncamente se elevará ao alto! Se caminhares, enfim, para trás, ah! ainda, uma derradeira parede, fechando tudo, fechando tudo horrível! - parede de Imbecilidade e Ignorância, te deixará num frio espasmo de terror absoluto...

$\mathrm{E}$, mais pedras, mais pedras se sobreporão às pedras já acumuladas, mais pedras, mais pedras... Pedras destas odiosas, caricatas e fatigantes Civilizações e Sociedades... Mais pedras, mais pedras! E as estranhas paredes hão de subir, longas, negras, terríficas! Hão de subir, subir, subir mudas, silenciosas, até às Estrelas, deixando-te para sempre perdidamente alucinado e emparedado dentro do teu Sonho..."22

Essa prisão que encerra, que encarcera, que torna a massa ao mesmo tempo criminosa e vítima, pode ser pensada como inerente tanto ao sujeito quanto à cultura, sem que isso signifique ou leve, é claro, a uma conformação. Leva antes a uma deformação, do soneto à prosa.

Para entrar mais especificamente no assunto, é válido mencionar o texto escrito por Walter Benjamin entre 1920 e 1921, denominado "Sobre crítica à violência" ("Zur Kritik der Gewalt”). Nesse ensaio, a violência é pensada circunscrita ao direito e à justiça ${ }^{23}$, a fim de colocar em jogo a ambiguidade inerente ao direito fundado e mantido (força policial) a partir da violência. $\mathrm{O}$ que Benjamin percebia na sua releitura kantiana, Freud que já havia em grande medida desenvolvido a disciplina da psicanálise por essa época, pensava a partir da cisão do sujeito em consciente e inconsciente. Afinal, quando Freud pensa a civilização com esse pressuposto, coloca em outros termos o mesmo problema. 
Para o pai da psicanálise, a cultura ${ }^{24}$ é definida como a junção entre os saberes relativos ao domínio da natureza (técnica) e as instituições mediadoras das relações humanas, por exemplo, na divisão dos bens acessíveis (economia). Nesse sentido, argumenta o pensador ao tratar do assunto em $O$ futuro de uma Ilusão, no domínio da natureza é possível ver avanços - é indubitável o constante e cada vez mais presente desenvolvimento da técnica. Já no que diz respeito às relações humanas, que também muito se modificou no decorrer das épocas, no entanto, não é certo que tenha se modificado de maneira crucial, uma vez que continuam embasadas na coerção e na repressão de impulsos cujo resultado é uma grande parcela de descontentamento entre os seres humanos.

A repressão desses impulsos, pressuposto básico da civilização, leva inexoravelmente à criação de leis e, em última instância, o que percebe Freud ao trabalhar com as histéricas no fim do século XIX, bem como Walter Benjamin analisando a cultura no entre-guerras, é que o progresso técnico aumenta essa repressão e, consequentemente, a violência inerente ao ato repressor explode em alguma via alternativa. Portanto, pelo menos provisoriamente, pode-se pensar que o mito do progresso civilizatório vai na mão contrária da análise de Freud e Benjamin, esse último, conhecido pela elaboração da teoria de um tempo catastrófico que reconhece em todo e qualquer documento da cultura, um documento de barbárie.

Assim, é lícito inferir que a condição da vida moderna é crítica. Essa crise diante de uma repressão cada vez maior não deixa de se relacionar também com o aumento da transgressão. Daí que Benjamin, ao estudar a modernidade, entenda que o gênero policial é iminentemente moderno, dependente da massa e do crime - essa transgressão à lei intensificada pela técnica. A massa, imenso corpo que dá uma dimensão monstruosa ao mito, como nunca antes vista na história da humanidade, aparece, assim como em Baudelaire, não como um tema, mas como uma presença ausente na poesia de Cruz e Sousa. No caso de Berna, a massa é incorporada à cena na grande maioria das performances. Desse modo, é possível aproximar o gênero policial da manifestação artística dos autores estudados, desde que se entenda que tal gênero não pode mais ser sustentado como homogêneo, já está promíscuo e retorcido tal qual a boca negra. No gênero policial esvaziado, o detetive não cumpre papel de descobridor da verdade, consciente ele mesmo que ela não se dá a ver. O detetive é aquele que busca incessantemente encontrá-la. Essa busca, assim como a do arquivista e a do perito criminal, apresenta versões que, se de um lado, apostam em um sentido, na razão, de outro, reconhecem a falta de essência do sentido, o caos e a loucura. A transgressão moral indispensável nesse procedimento, acentuada pelos nus de Berna,
24. A cultura (kultur) em Freud não se diferencia de civilização. 
25. Ainda que Bataille insista em se afastar dos postulados de Sigmund Freud.

26. BATAILLE, Georges. $O$ erotismo, 1987, p.20.

27. Falando da religião cristã, da qual a sua teoria do erotismo se afasta, Bataille afirma que ao condenar o erotismo, essa religião torna-se em certo sentido, pouco religiosa - no que tange justamente à questão da continuidade do ser. pelos problemas baixos, fétidos, rebaixados de Cruz, colocam o artista também em posição do transgressor. Nesse sentido, o detetive confunde-se com o criminoso.

\section{O crime e o mercado}

A violência, que já estava prefigurada na base do direito na teoria benjaminiana, é reformulada em Georges Bataille, por uma via mais freudiana ${ }^{25}$, em termos do erotismo. Pensando em termos de continuidade e descontinuidade dos seres, o filósofo francês remonta à separação do homem e do animal para tratar da questão:

Sabemos que os homens fabricaram instrumentos e os utilizaram a fim de prover sua subsistência, depois, sem dúvida, bastante depressa, suas necessidades supérfluas. Resumindo, eles se distinguiram dos animais pelo trabalho. Paralelamente, eles se impuseram restrições conhecidas como interditos. Essas interdições essencialmente - e certamente - recaíram sobre a atitude para com os mortos. É provável que elas tenham tocado ao mesmo tempo - ou pela mesma época - a atividade sexual. ${ }^{26}$

O trabalho, a consciência da morte e a sexualidade contida separam, portanto, na teoria bataillana, o homem do animal. É, no entanto, a sexualidade contida, isto é, o sexo envergonhado, que faz surgir o erotismo. $O$ interesse do filósofo é entender o erotismo a partir daquilo que ele chama de experiência interior, uma sorte de religiosidade vinculada a ele, que podemos atrelar de maneira mais ampla ao estudo do mito pela via negativa.

Para Bataille, no erotismo, assim como na religião, o "eu" descontínuo - isto é, que morre, que não é eterno - se perde. Aí o ser encontra a sua continuidade ${ }^{27}$. A religiosidade, enquanto experiência interior, a que Bataille se refere, é imensamente trabalhada na obra de Cruz e Sousa seja pela via do erotismo, seja pela via dos rituais. Exemplar nesse sentido é o poema, que também remete ao grande nome do gênero policial - Poe - denominado "Pressago" que se apresenta da seguinte forma nos oito dísticos finais:

Negras aves de rapina

Mostram a garra assassina.

Sob o céu que nos oprime

Languescem formas de crime.

Com os mais sinistros furores,

Saem gemidos das flores. 
Caveiras! Que horror medonho!

Parecem visões de um sonho!

A morte com Sancho Pança,

Grotesca e trágica dança.

E como um símbolo eterno,

Ritmos dos Ritmos do inferno.

No lago morto, ondulando,

Dentre o luar noctivagando,

O corvo hediondo crocita

Da sombra d'Iago maldita! ${ }^{28}$
28. SOUSA, João da Cruz e.

Poesia Completa, 1995, p. 135137.

29. Interessante observar que na missa o corpo sacrificado é objetualizado alegoricamente no pão e no vinho, alimentos da fé da comunidade cristã.

30. A fotografia consta na rede com o direito autoral $\mathrm{da}$ artista que, consultada, cedeu gentilmente o uso da sua imagem para este artigo.

Os dísticos também em versos octassílabos, recorrem ao Otello shakeaspereano, rememorando Iago, o grande vilão do drama, para montar um cenário espectral. O cenário composto pelas camadas de tempo eternizam o vilão como sombra, fantasma, imagem dos crimes nefandos do passado, do presente e, assim como o crocitar do corvo nos sugere, do futuro (equivalente ao nevermore de "O corvo" de Poe). O cenário trata-se de um ritual que marca o retorno da violência, muito próximo do que seria a missa no que tange ao rito de sacrificial crucificador do $\mathrm{Cristo}^{29}$. O que Cruz com seu erudito repertório faz ecoar na poesia, Berna Reale ecoa na performance cujo título sintomático é Quando todos calam. Segue abaixo uma fotografia que rememora a performance referida:

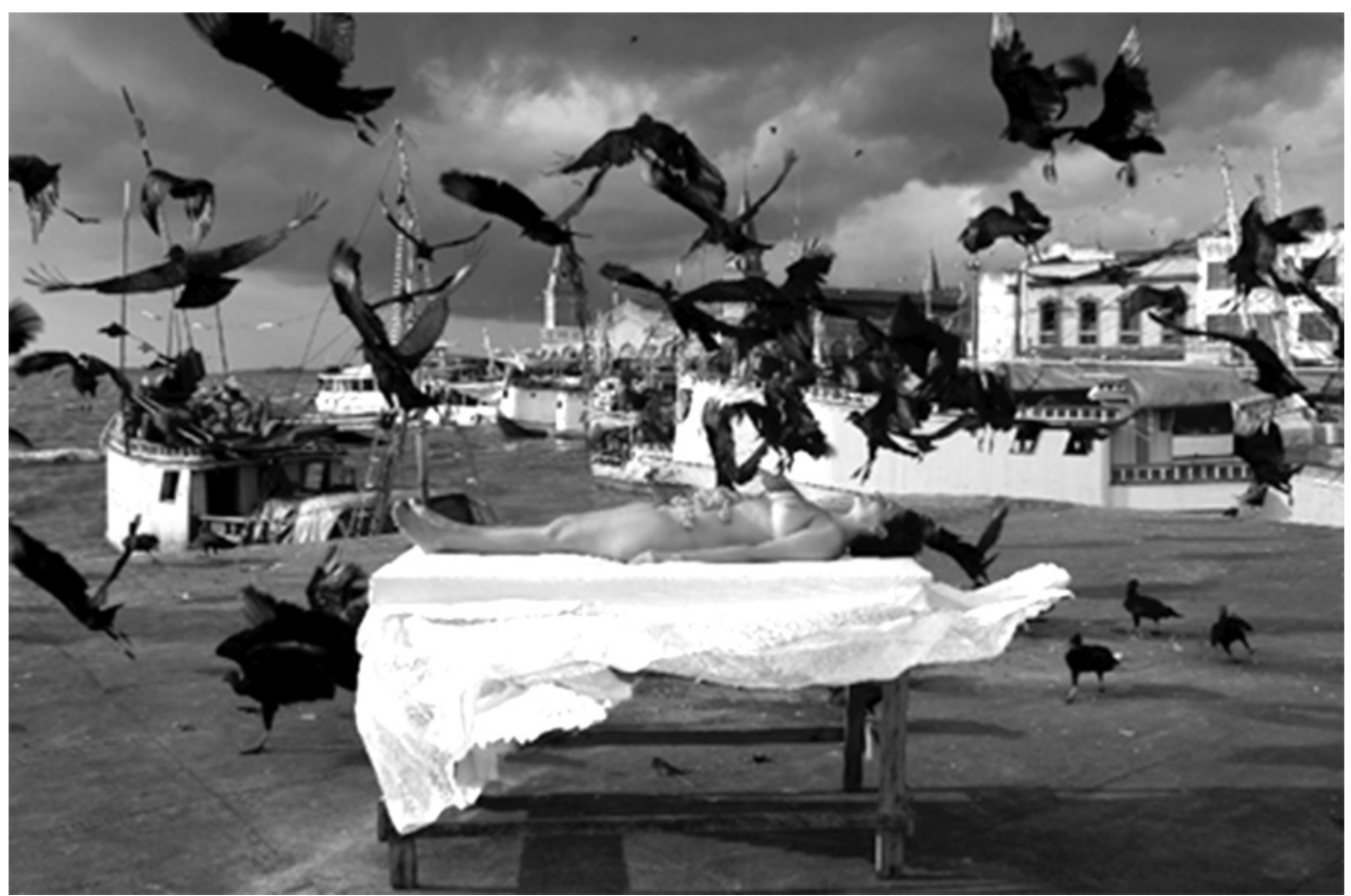

fig.02 - Fotografia tirada durante a performance

"Quando todos calam” da artista Berna Reale, realizada em 2009, no mercado Ver-o-peso. ${ }^{30}$ 
31. BATAILLE, Georges. $O$ erotismo, 1987, p.24.

32. Bataille aí incorre num erro no afã de tentar ligar esse movimento à experiência interior, afirma que o interdito - base da cultura - não vem de fora. No entanto, sabemos que, para citar o exemplo citado pelo filósofo, a angústia que acompanha à transgressão é variável de acordo com a cultura. Isto é, a transgressão causa angústia porque não estamos agindo como o outro espera, não pela transgressão em si.

33. O carnaval vinculado ao cristianismo é prova viva dessa íntima ligação. Sobre esse assunto, é interessante mencionar que o crítico Eugênio D'ors no seu estudo sobre o Barroco entende a necessidade do Carnaval e seu caráter de exceção/transgressão (assim como o das férias) seja para a liturgia católica, seja para o utilitarismo trabalhista, como uma instituição Barroca.
A artista passou quatro horas deitada nua com vísceras à mostra no mercado público da capital paraense Ver-o-peso. As aves de rapina performatizando uma grotesca dança, as vísceras sob o corpo sugerindo um cadáver servido à mesa com toalhas brancas, tanto em Berna quanto no poema de Cruz traz-se novamente à baila uma violência sofrida no corpo, ferida exposta no mercado, sempre comercial, seja o público seja o literário que, assim como gostaria de defender, poderia ser atrelado à imagem de um crime que colocaria em jogo o ritual da própria arte.

O crime, nesse caso, é pensando conceitualmente dentro da ideia de interdito e transgressão oriunda do pensamento bataillano. Para o teórico, o interdito - que se opõe à "natureza”- vincula-se estritamente à transgressão. Transgredir o interdito não significa regredir à natureza, isso porque, assim como frisou Bataille, a transgressão "suspende o interdito, sem suprimi-lo. Aí esconde-se o suporte do erotismo e se encontra, ao mesmo tempo, o suporte das religiões." ${ }^{31}$ Levada às últimas consequências, a tese de Bataille é de que a violação é cúmplice da lei. ${ }^{32}$

A transgressão, portanto, está para violência, assim como o interdito (a razão) está para o trabalho. Vê-se nessa fórmula justamente a intimidade desses polos quando os excessos, outro modo de falar da violência, são previstos em festas e jogos, por exemplo, que apesar de muitas vezes, serem moralmente condenados, são fundamentais para essa estrutura ${ }^{33}$. A lei que sustenta a cultura, o interdito, tem por objeto a contenção da violência e tem como pressuposto a transgressão. Portanto, a violência está no cerne do problema mesmo quando trabalho tenta excluir a reprodução sexual e a morte, isto é, a cultura é fundamentada na violência.

A morte e a reprodução, sorte de violência que interrompe a vida ou que lembram que a vida é descontínua, carregam para o morto e para o ato sexual o perigo iminente. A ameaça ali trazida por contágio, imagem do nosso destino, gera, como vimos, horror e nojo. O Mesmo efeito que cria a virulência ativa da putrefação implícita nas vísceras à mostra e no cerco dos urubus da performance de Berna, ou do lodo abjeto, do sangue roxo dos fetos, dos doentes terminais, que Cruz reiteradamente repete na sua poética.

A vida humana, definida a partir do trabalho ou da razão é também fundamentada no excesso e na loucura, isso nos mostra o pensamento de Bataille, a poesia de Cruz e as performances de Berna. Há uma parte da vida, aquela chamada de maldita, que pertence à esfera do inútil. Ou seja, o homem nunca será redutível à utilidade. E o "não" à natureza - materializado no trabalho - concretiza-se no interdito que tem por 
objeto a morte e a reprodução, no entanto, não caracteriza uma oposição de todo. A transgressão aparece aí como aceitação do excesso e da violência. Ou, pensando na definição de erotismo bataillana, a transgressão é a aprovação da vida até na morte.

A emergência da violência nos artistas estudados inevitavelmente liga-se à aparição de um nefando crime. Dito de outra maneira, vincula intimamente a arte a esse ato transgressor. É reivindicando a visão da modernidade enquanto cena do crime de Poe e de Baudelaire que Cruz entende a arte enquanto uma transgressão da lei: "era mister romper o Espaço toldado de brumas, rasgar as espessuras, as densas argumentações e saberes, desdenhar os juízos altos, por decreto e por lei, e enfim, surgir..." ${ }^{34} \mathrm{O}$ artista é portanto um marginal ${ }^{35}$, aquele que se rebela, isto é, aquele que etimologicamente, retorna à guerra, reincide na violência, no excesso, na abundância. Afinal, cabe lembrar, é no inferno que o poeta se encontra com Baudelaire no poema-ensaio "No Inferno". Lugar do transgressor primeiro, Lúcifer, e de todos os outros rebeldes. Lugar dos bandoleiros, bandidos, dos gueux ${ }^{36}$, lugar de Fortunato, o emparedado no conto de Poe. A abundância de sons, estesias, imagens e palavras não deixa de ser uma repetição diferenciada da tensão ou passagem que implica sempre a violência, seja a do rebelde, seja a do erotismo do corpo.

É fundamental lembrar ainda que essa abundância ( $a b$ undare, $a b$ - unda - aquilo que transborda, que vai além, que transgride a lei) é sintomática em toda obra no que tange ao próprio vocábulo, uma vez que a palavra mais recorrente nos poemas é a palavra onda e suas variações, ondulações, onduladas, não raro acompanhada da palavra ou alusão à palavra vagar. No poema "No Inferno", por exemplo, tem-se: “[...] as almas dos Meditativos e Sonhadores, tantalizadas de tédio, vagavam e ondulavam insaciavelmente..." ${ }^{37}$. Não é à toa também que esses vocábulos aparecem juntos. Vagar, essa errância aí prevista daquele que vagueia, do vagabundo, do nômade, do bêbado, do poeta, pressuposta nas divagações mallarmaicas, deu na língua francesa origem a palavra onda - vague. Além do vagar, essas ondas nos remetem, claro, ao som, ou à maneira pela qual ele se propaga - traço sobressalente da musicalidade, a arte não representativa.

Esse lugar de excesso de caráter ressonante é materializado pelo uso abundante de aliterações, principalmente em "v" e em "s", uma das marcas da poesia de Cruz e Sousa ${ }^{38}$ : "Uma tristeza fina e incoercível errava nos tons violáceos vivos daquele fim suntuoso de tarde aceso ainda nos vermelhos sanguíneos." ${ }^{39}$ A repetição do "v" é utilizada na sugestão onomatopaica do próprio vento, assim como se poderia ler a do "s" como uma onomatopeia da própria onda - movimento marítimo. No caso de "Violões que choram" esta sugestão é en-
34. SOUSA, João da Cruz e. Poesia Completa, 1995, p. 662.

35. Em algumas passagens do poema há uma maior explicitação da condição de revoltado do artista: "Desde que o Artista é um isolado, um esporádico, não adaptado ao meio, mas em completa, lógica e inevitável revolta contra ele, num conflito perpétuo entre a sua natureza complexa e a natureza oposta do meio [...]" (Ibidem, p. 667)

\section{Em 1876, Richepin}

publicou La chanson des gueux, sua obra mais conhecida e importante, tornada célebre na época por ter sido apreendida e causado a condenação do autor por "atentado aos bons costumes", com pena de um mês de reclusão. Cruz e Sousa leu Richepin, utiliza a palavra "gueux" em vários momentos e pode-se deduzir que os "marginais" da obra do poema francês encontraram ressonâncias nas experiências do negro à margem da sociedade burguesa em Desterro no fim do século XIX.

\section{Ibidem, p. 610.}

38. Sobre a aliteração em "v", importante lembrar da metade da estrofe mais famosa de Cruz e Sousa contida na sétima estrofe do poema "Violões que choram": "Vozes veladas, veludosas vozes, /Volúpias dos violões, vozes veladas, /Vagam nos velhos vórtices velozes/Dos ventos, vivas, vãs, vulcanizadas". (Ibidem, p.123)

39. Ibidem, p. 658-659. 
dossada pelo sentido das palavras, afinal as vozes veladas vagam nos ventos. É no vento, no sopro, portanto, no movimento, que essas vozes veladas transitam. É interessante lembrar que as vozes que ecoam do poema "Violões que choram", são sempre gritos, gemidos, murmúrios, sussurros das águas, prantos, nunca a fala.

Nas performances pensadas por Berna, é também no movimento que as vozes veladas ressoam. Não há fala. Há, no cenário de Quando todos calam, o mar, os urubus, o movimento próprio do mercado, ponto de prostituição, de venda de carnes, de murmúrios e grunhidos, acompanhados pelo barulhos do vento e das ondas que participam com aquele corpo nu, oferecido numa sorte de eterno ritual do retorno da violência. É a lembrança, ou melhor, um déjà vu da história.

A arte moderna, é possível convencionar, emergente de maneira mais cabal no Brasil com a poesia de Cruz e Sousa, traz à baila, junto com a ascensão da técnica, a fragmentação, a decomposição e a dispersão, isso nos mostrava Eliane Robert Morais no seu livro O corpo impossível. A Salomé, dançarina que pelo viés erótico, consegue a cabeça de João Batista, retomada nos poemas de Cruz enquanto serpe venenosa ou a personagem com vísceras à mostra deitada numa mesa branca no mercado público definem e são definidas por esse mundo em pedaços. A violência inerente à vida e à arte que foi abordada aqui, que levou Benjamin a entender a história enquanto ruína - é capturada fragmentariamente pelos artistas que recriam as sensações instáveis e incômodas do presente.

Essas sensações, no entanto, assim como foi proposto nessa leitura, ligam-se à emergência de subjetividades cindidas atravessadas pela técnica e, intimamente vinculada a ela, pelo avanço do capitalismo nas suas mais diversas formas. O que transplanta para o campo da arte a questão do seu próprio lugar diante desse cenário. Ou, dito de outra forma, a pergunta com a qual se encerra esse artigo é qual o lugar do corpo (artístico) no mercado (literário/artístico)? Parece ser essa a questão que, no Brasil, a começar com Cruz, aparece também em Berna. De fato, assim como percebemos, o problema da violência aliada à exploração de trabalho e ascensão do capitalismo pode ser colocado em termos de violência de mercado, aquela que a arte tenta escapar, transgredir, ser o excesso, mas que já está, com a queda da sua aura, fadada à profanação. Devolvida à esfera do uso, a arte é o corpo que resiste, seja no grito, seja na mudez. A ressonância da lógica do "açougue”, de Cruz a Berna, no entanto, alegoria de um corpo passível de propriedade, portanto, de venda, não deixa escapatória. A crítica dessa violência que aparece aí, então, no domínio do mercado, é a crítica da identidade (de nação, de gênero, de raça), sem ser inocente, a arte sabe que não pode escapar de toda sorte de identificação, mas tenta ritualmente colocar-se no lugar do singular. 


\section{Referências}

BATAILLE, Georges. “Boca”. In: Documents, 5, ano II, 1930. . O erotismo. Trad. Antonio Carlos Viana. Porto Alegre: L\&PM, 1987.

BENJAMIN, Walter. Escritos sobre mito e linguagem. Trad. Susana Kampff Lages e Ernani Chaves. - São Paulo: Duas Cidades; Ed. 34, 2011.

COUTINHO, Afrânio. Cruz e Sousa. Rio de Janeiro:Civilização Brasileira; Brasília, INL, 1979 (Col.

Fortuna Crítica, v. 4).

DUQUE, Gonzaga. O poeta negro. In: COUTINHO, Afrânio. Cruz e Sousa. (Col. Fortuna Crítica, v. 4). Rio de Janeiro: Civilização Brasileira; Brasília, INL, 1979

FONSECA, Jair Tadeu. "Cruz e Sousa: as expansibilidades do emparedado”. In: Aletria: revista de estudos de literatura, v.9, 2003. Belo Horizonte: POSLIT/CEL, Faculdade de Letras da UFMG.

FREUD, Sigmund. O futuro de uma ilusão. Trad. Renato Zwick. Porto Alegre, RS: L\&PM, 2011.

. O mal-estar na civilização. Trad. Paulo César de Souza.

São Paulo: Penguin Classics Companhia das Letras, 2011.

LEMINSKI, Paulo. Cruz e Sousa. São Paulo: Brasiliense. 2003

NANCY, Jean-Luc. A la escucha.1a ed. Buenos Aires:

Amorrortu, 2007.

MORAIS, Eliane Robert. O corpo impossível. São Paulo:

Iluminuras, 2002.

MURICY, Andrade. “O cisne Negro: Cruz e Sousa”. In:

Revista Interamericana de Bibliografia. Washinton D.C. (1/2).

15-38, jan.-jun., 1962.

SOUSA, João da Cruz e. Poesia Completa, organização e introdução Zahidé Muzart. Florianópolis: FCC: FBB, 1995. 
